\title{
Characterization of unifloral honeys
}

\section{Persano Oddo 1, MG Piazza 1, AG Sabatini 2, M Accorti ${ }^{3}$}

\author{
1 Istituto Sperimentale per la Zoologia Agraria, Sezione di Apicoltura, Via L Rech 36, 00156 Rome; \\ 2 Istituto Nazionale di Apicoltura, Via S Giacomo 9, 40126 Bologna; \\ 3 Istituto Sperimentale per la Zoologia Agraria, Via Lanciola, Cascine del Riccio, 50126 Florence, Italy
}

(Received 15 February 1995; accepted 8 August 1995)

\begin{abstract}
Summary - The characterization of 14 types of Italian unifloral honeys was carried out on the basis of the organoleptic, microscopic (qualitative and quantitative melissopalynological analysis) and physicochemical properties (colour, moisture, ash, HMF, diastase, $\mathrm{pH}$, total acidity, electrical conductivity, specific rotation and sugars). The botanical origins of the examined honeys were Arbutus unedo L, Castanea sativa Mill, Citrus spp, Erica arborea L, Eucalyptus camaldulensis Dehnh, Hedysarum coronarium L, Helianthus annuus L, Rhododendron spp, Robinia pseudoacacia L, Taraxacum officinale Web, Thymus capitatus Hofmgg et LK, Tila spp, honeydew honey from Abies and honey from Metcalfa pruinosa honeydew. The synoptic picture emerging from the results can be used as a reference framework for the diagnosis of unifloral honeys.
\end{abstract}

honey / Italy / melissopalynology / physicochemical characterization / organoleptic analysis

\section{INTRODUCTION}

The very first problem that arises when approaching the subject of unifloral honeys is when to define a honey as unifloral. A continuous series of intermediate possibilities exists between a multifloral and a unifloral honey. At what point and on what basis does the unifloral/multifloral discrimination take place?

International standards specify that "honey may be designed according to floral or plant source if it comes wholly or mainly from that particular source and has the organoleptic, physicochemical and microscopic properties corresponding with that origin" (CAC, 1989, 6.1.4; EEC Directive, 1974, 7.4.a), but this does not mean much unless these properties are defined through the prescription of given limits for precise analytical parameters.

An extensive study was carried out on the most common parameters used in honey analysis, to identify a characteristic range of values for the different unifloral types. Numerous contributions have been published on this subject (Persano Oddo and Amorini, 1985; Accorti et al, 1986; Persano Oddo et al, 1986, 1988a, b, 1990, 1991; Sabatini et al, 1989, 1990; Piazza et 
al, 1991). The aim of the present paper is to complete the results presented in previous papers by adding new data obtained after their publication, and to provide a synoptic picture, which can be used as a reference framework for the diagnosis of unifloral honeys.

Data are related to Italian productions, but bibliographic comparisons generally show that the honey characteristics are affected more by their botanical origin than by their geographic provenance. In some cases discrepancies were noted between our results and those presented by other authors on the same honey types, but they could mostly be accounted for by differences in analytical methods or by the botanical origin of the honey, which was not exactly the same (same genus, different species, for instance). Some geographic aspects (climate, soil acidity or other pedologic conditions) may, however, influence the nectar and honey composition. Therefore, caution must be taken in applying the ranges characteristic of Italian unifloral honeys in other countries.

\section{MATERIALS AND METHODS}

More than 2000 honey samples of different botanical origin, declared as unifloral by the producer, were collected and analyzed over a period of 10 years.

Three analytical approaches were used, for the characterization of the different honey types, with reference to organoleptic properties (Gonnet and Vache, 1985), qualitative and quantitative melissopalynological analysis (Louveaux et al, 1978) and physicochemical parameters. These parameters included colour (Aubert and Gonnet, 1983), moisture, ash, hydroxymethylfurfurale (HMF) and diastase (CAC, 1989), pH, total acidity (White et al, 1962), electrical conductivity (Louveaux et al, 1973), specific rotation (Battaglini and Bosi, 1973; Junk and Pancoast 1973) and sugars (Sabatini et al, 1984).

The criteria for selecting samples and defining unifloral groups were based on the organoleptic evaluation and on the uniformity of behaviour with regard to the various analytical parameters. Fourteen honey types from the following botanical origins were thus selected and described: Arbutus unedo L; Castanea sativa Mill; Citrus spp; Erica arborea L; Eucalyptus camaldulensis Dehnh; Hedysarum coronarium L; Helianthus annuus L; Rhododendron spp; Robinia pseudoacacia L; Taraxacum officinale Web; Thymus capitatus Hofmgg et LK; Tilia spp; honeydew honey from Abies; and honey from Metcalfa pruinosa honeydew. ( $M$ pruinosa (Say) is a Flatid planthopper which has spread in north-eastern Italy over the last few years. This polyphage insect parasites on many different plant species. Its honeydew is actively foraged by bees which then produce a characteristic honey (Barbattini et al, 1991).) Further details on materials and methods and on bibliographic comparisons with other studies can be found in the quoted literature.

\section{RESULTS AND DISCUSSION}

\section{Organoleptic properties}

The organoleptic properties are reported in table I. Descriptions can only provide some general information, due to the difficulty of giving an exact 'translation' of sensorial perceptions in words. On the other hand, the possibility of correctly diagnosing the botanical origin of the honey through the sensorial analysis is strictly bound to the personal ability and experience of the taster.

\section{Melissopalynological characteristics}

The melissopalynological data reported in table I include the minimum percentage of the specific pollen, the absolute content of pollen grains in $10 \mathrm{~g}$ honey and the representative class (according to Louveaux et al, 1978) found in the selected samples.

Honeys from Robinia, Citrus, Tilia, Rhododendron, Arbutus and Thymus have under-represented pollen (class I), so the 
percentages of the respective pollens in unifloral honeys are generally low to very low. The most typical ranges are 10 to $20 \%$ for Citrus and Arbutus, 15 to $30 \%$ for Robinia and Thymus and 30 to $60 \%$ for Rhododendron. Honey from Tilia can even have no Tilia pollen at all, because of the sterility of many cultived varieties of this plant.

Castanea and Eucalyptus honeys belong to the over-represented class (III and IV) and in unifloral samples their respective pollens are greater than $90 \%$ (in most of Castanea honeys higher than $95 \%$ ) and can make about $100 \%$ of the pollens.

Erica and Hedysarum behave like 'normal' honeys, for which $45-50 \%$ of the specific pollen is required to be considered unifloral. The most typical range is 60 to $90 \%$ for Hedysarum, with a PK/10 g of 10000 to 50000 , and 50 to $80 \%$ for Erica, which is usually richer in pollen (PK/10 g from 50000 to 150000 ). Hedysarum honey could be assumed to be affected by a secondary contamination, since the species is actively visited by bees for pollen. This would explain the high percentage associated with a relatively low absolute pollen content.

Helianthus can behave as a normal or under-represented honey. In most of the unifloral samples, it composed 15 to $50 \%$ of the pollen found, with an absolute number of pollen grains not exceeding $20000 / 10 \mathrm{~g}$ honey. In some other samples, both the pollen percentage and the $\mathrm{PK} / 10 \mathrm{~g}$ were higher (60 to $90 \%$ and 25000 to 50000 , respectively).

Taraxacum honey is characterized by low percentages (usually 5 to $15 \%$ ) and a relatively high absolute pollen content (class II), because of its almost constant contamination with Salix (which is over-represented). This feature seems to be peculiar to Italian Taraxacum honeys.

Honeydew honeys show great variability in their palynological characteristics. Both the absolute pollen content and the honey- dew elements/pollen (HDE/P) ratio are spread over a very large range of values. It is to be noted that in Abies honeydew the $\mathrm{HDE} / \mathrm{P}$ ratio rarely complies with the value of 3 given as the minimum limit for diagnosing honeydew honeys from central Europe (Louveaux et al, 1978).

\section{Physicochemical characteristics}

The physicochemical parameters (tables II and III) have a different diagnostic value for the various groups. Generally speaking, the higher or lower values are a more characteristic feature than medium values, because wider overlapping occurs in the medium area. By means of analysis of variance, electrical conductivity proved to have the highest discriminatory power (Stefanini, 1988). Moisture and HMF are more important for quality evaluation, but also show a certain variability according to botanical origin, probably due to the production period (water content) or to other composition factors. For these parameters the range of variability is not given in table II, because honeys with high water and HMF content were rejected, to avoid including low quality samples.

Robinia, Hedysarum, Rhododendron and Citrus honeys are characterized by their very light colour and low conductivity and ash values; Robinia and Citrus have a low diastase content. Robinia also shows a particular sugar composition, with a high fructose and a low glucose content and consequently a high fructose/glucose (F/G) and a low glucose/water (G/W) ratio, which determine its liquid physical state. Hedysarum is further distinguished by its low $\mathrm{pH}$ and relatively high acidity; Rhododendron has particularly low negative specific rotation values.

Castanea and the 2 honeydew honeys are the darkest. They also have the highest $\mathrm{pH}$, electrical conductivity and ash values. In addition, Castanea honey, a typi- 


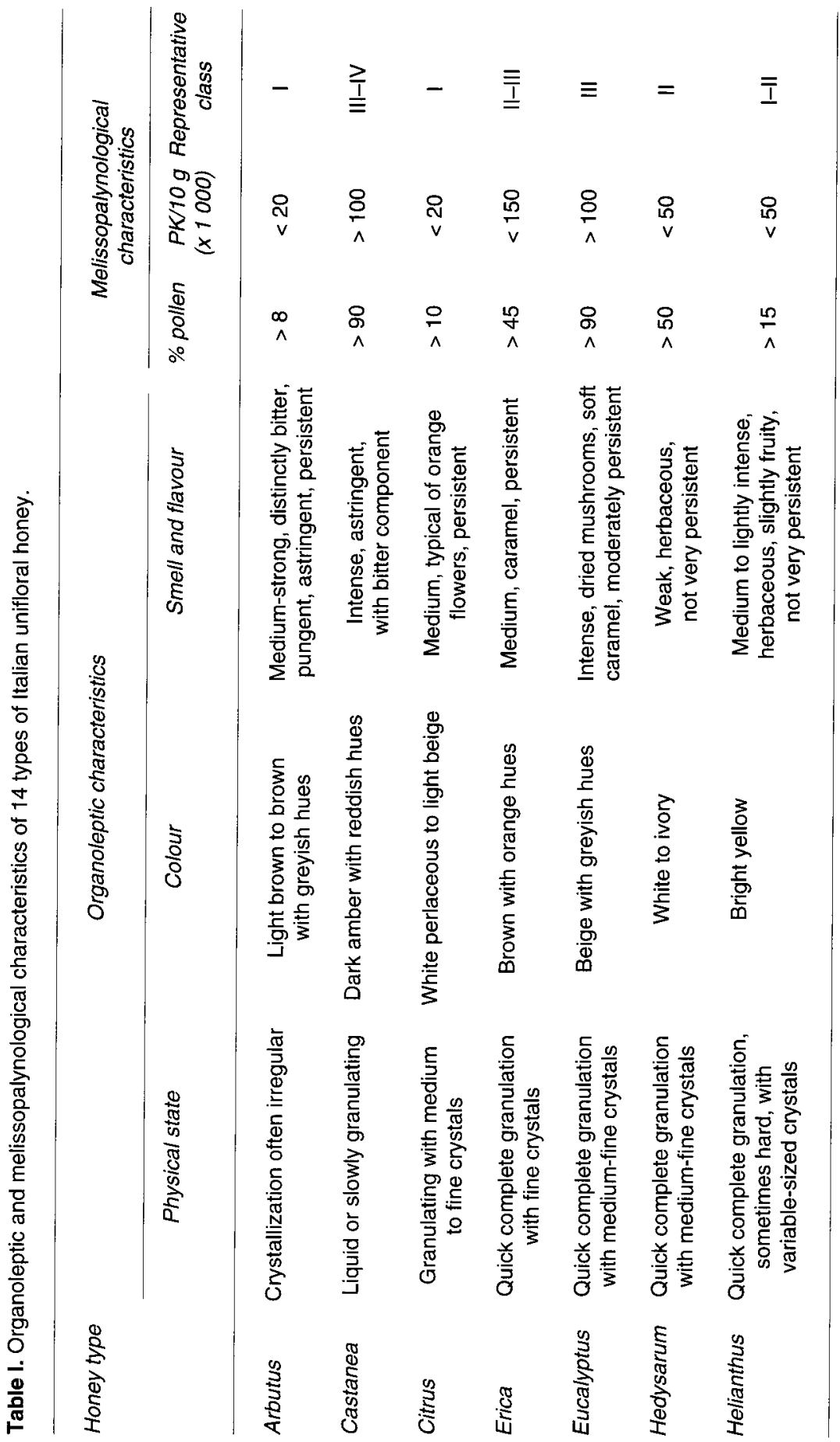




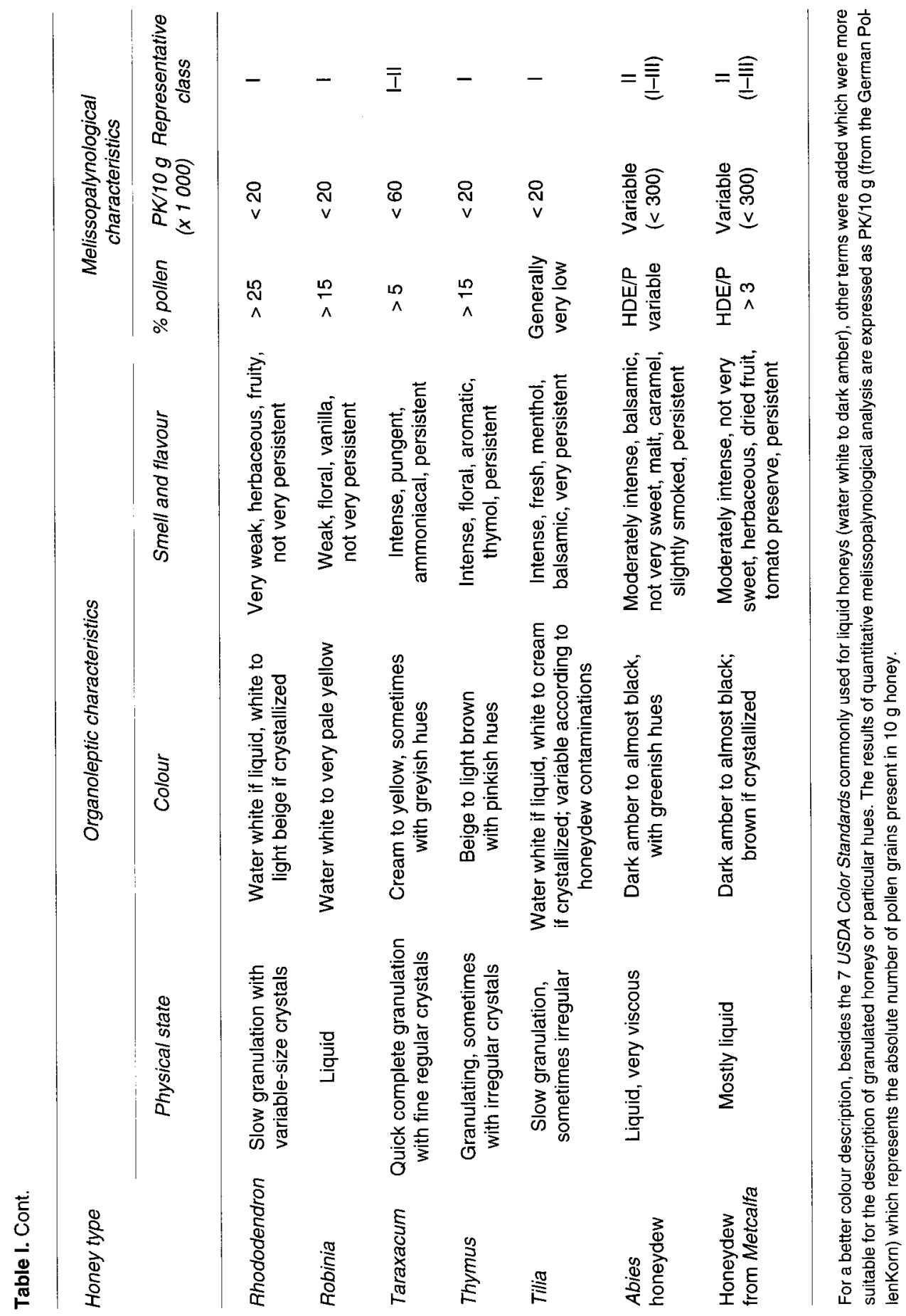




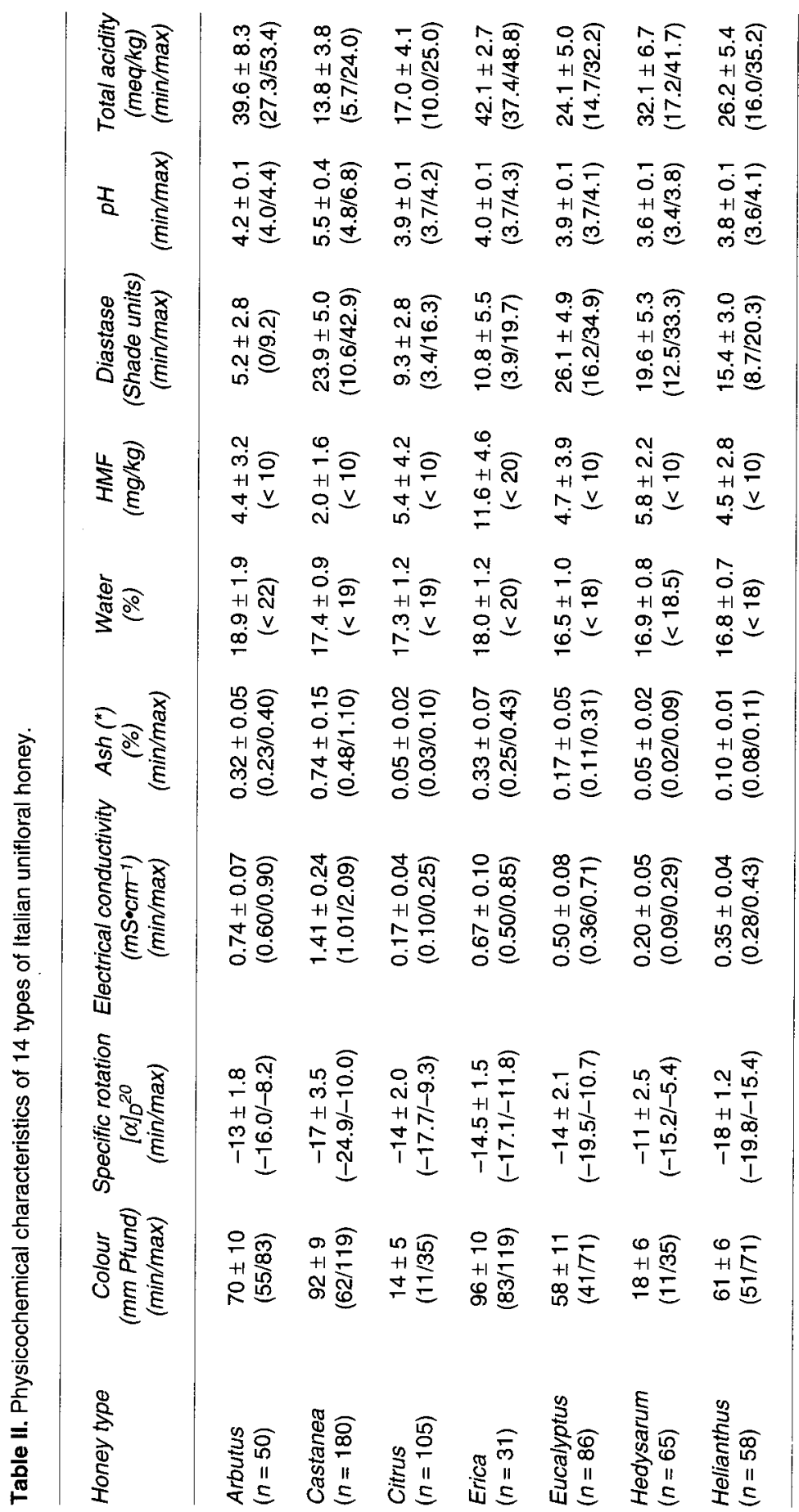




\begin{tabular}{|c|c|c|c|c|c|c|c|}
\hline 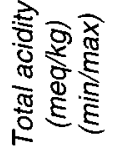 & 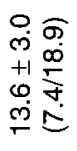 & 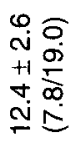 & 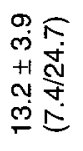 & 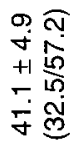 & 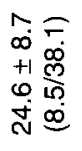 & 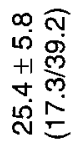 & 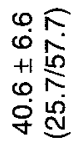 \\
\hline : & 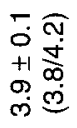 & 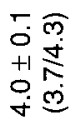 & 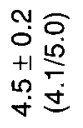 & 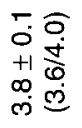 & 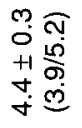 & 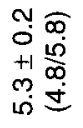 & $\begin{array}{l}\text { サ. } \\
0 \\
+1 \\
+1 \\
0 \\
\text { in } \\
\text { in }\end{array}$ \\
\hline 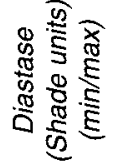 & 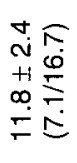 & 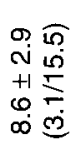 & 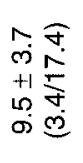 & 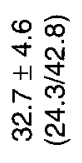 & 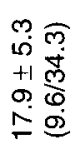 & 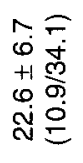 & 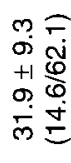 \\
\hline & 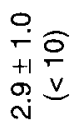 & 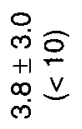 & 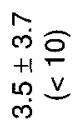 & $\begin{array}{l}\stackrel{+}{\infty} \widehat{10} \\
+1 \frac{1}{v} \\
\stackrel{v}{N}\end{array}$ & $\begin{array}{l}\dot{v} \\
i \\
+1 \\
\sim \\
\stackrel{+}{+} \underline{v}\end{array}$ & $\begin{array}{l}\stackrel{0}{-} \sigma \\
+1 \\
\stackrel{+}{\mathrm{O}}\end{array}$ & 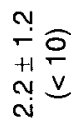 \\
\hline & $\begin{array}{l}\stackrel{\varphi}{0} \\
+10 \\
\dot{0}= \\
\stackrel{0}{0}\end{array}$ & 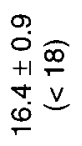 & 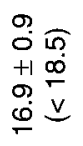 & 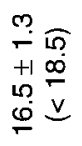 & 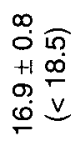 & 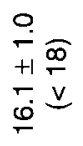 & $\begin{array}{l}\infty \\
0 \\
+1 \\
0 \\
0 \\
0\end{array}$ \\
\hline 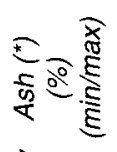 & ষ $\frac{\widehat{E}}{\dot{g}}$ & $\begin{array}{l}\overline{0} \\
0 \\
0 \\
+1 \\
0 \\
0 \\
0 \\
0 \\
0\end{array}$ & 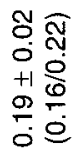 & 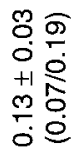 & 品 & 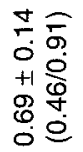 & 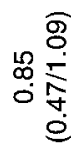 \\
\hline
\end{tabular}

:

Sิ

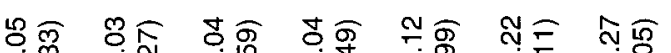

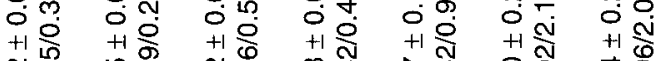

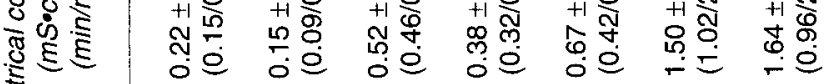
总

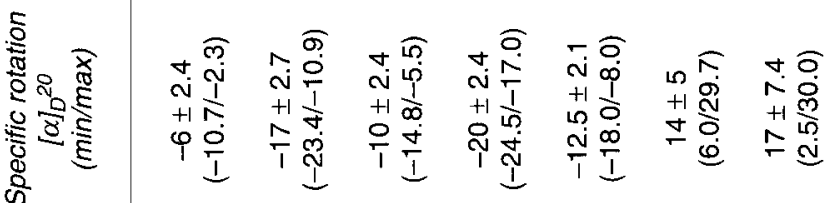

产京离 OE ह

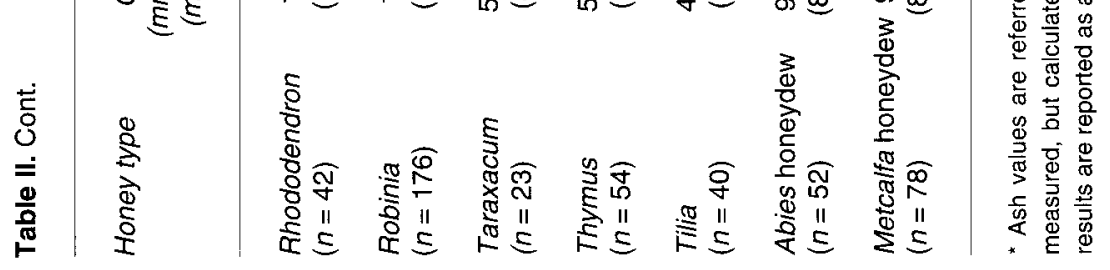
营客 


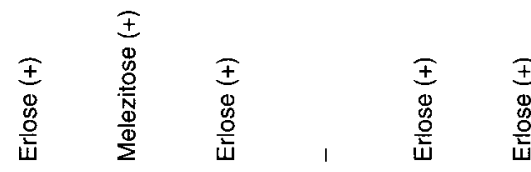

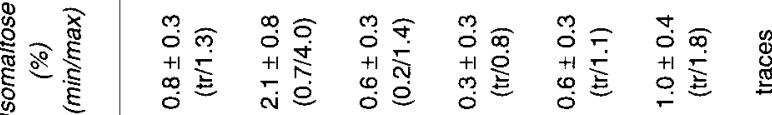

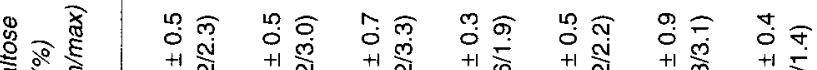

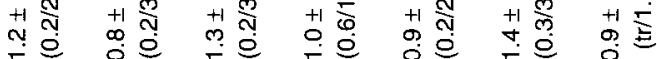

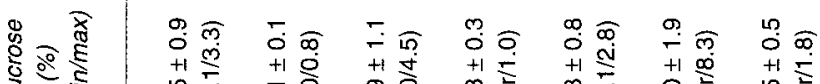

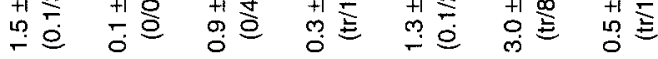

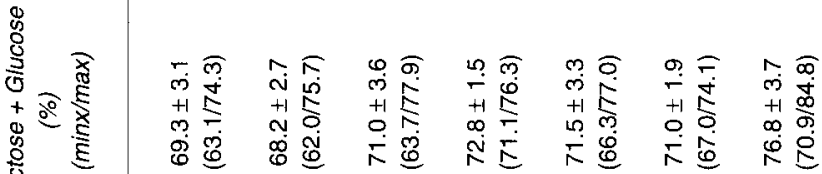
这

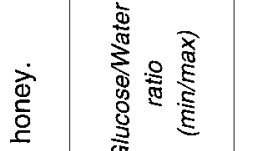

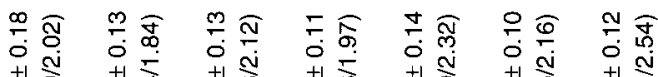
I

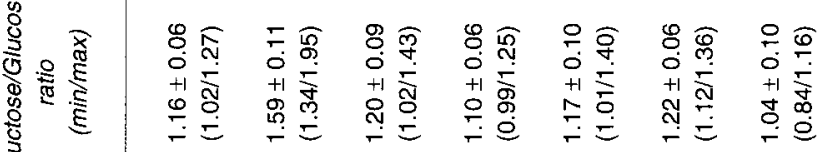

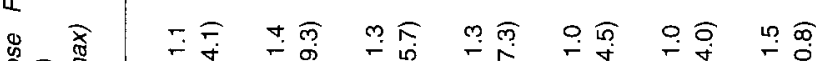

过

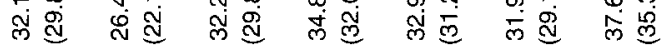

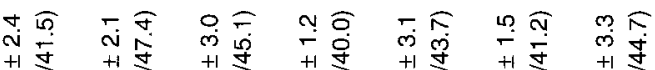

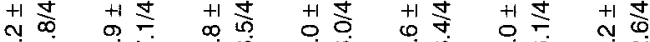

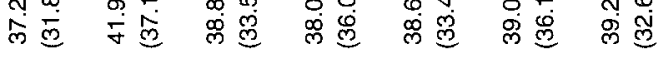




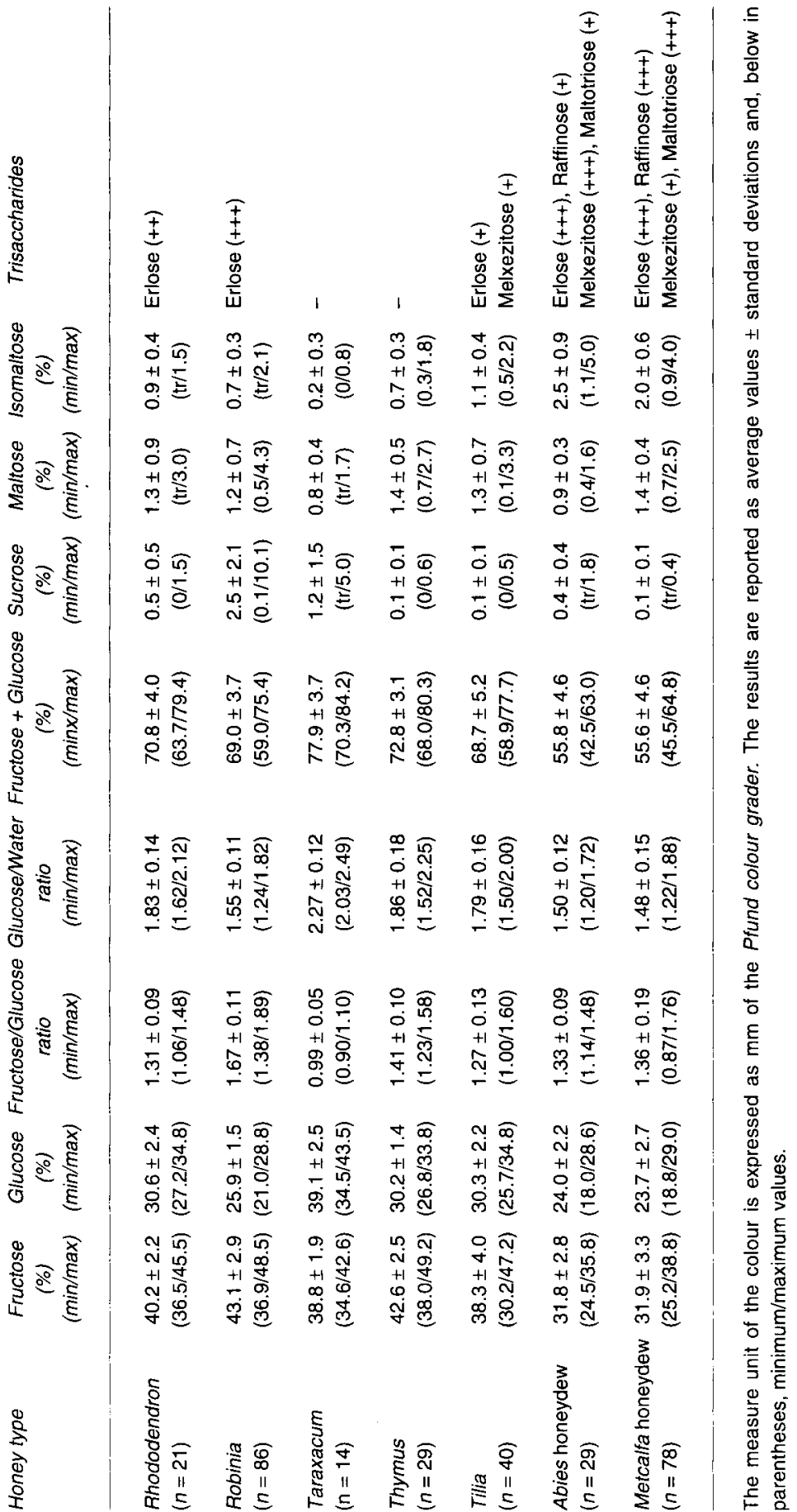


cally liquid honey, is characterized by a high fructose and a low glucose content, with a high $F / G$ and a low G/W ratio. Honeydew honeys have many other distinctive features. They are the only honeys with positive specific rotation values and present a typical glucide spectrum, poor in monosaccharides and rich in di- and trisaccharides (in particular, melezitose in Abies honeydew and maltotriose in honeydew from Metcalfa). Metcalfa honeydew also shows the highest acidity and diastase values.

Both Helianthus and Taraxacum honeys have a very high monosaccharide (particularly glucose) content, giving rise to a very high $G / W$ and a very low $F / G$ ratio. This is typical for honeys which granulate rapidly. Taraxacum is also characterized by its low acidity and diastase content; Helianthus has a very typical bright yellow colour.

Erica and Arbutus honeys have high moisture and acidity, low diastase and quite high ash and electrical conductivity, midway between the honeys from nectar and those from honeydew and Castanea. Erica is also characterized by its uncommonly high HMF content, exeeding that of all the other honey types, and by its dark colour with orange hues.

For Thymus honeys the most diagnostic parameters are acidity, diastase and specific rotation, all 3 showing very high values.

Eucalyptus and Tilia honeys are less easily identifiable on the basis of their physicochemical values, because of their 'average' behaviour. Tilia also shows great variability, probably due to the contaminations that frequently occur with Tilia honeydew. The microscopic examination is not very helpful either, because Eucalyptus is over-represented, and many cultivated varieties of Tilia are extremely under-represented. For these honeys, therefore, the organoleptic analysis is the most significant diagnostic criterion.
An important remark concerns the compliance of these unifloral honeys with international standards. Some of the types studied have characteristics that go beyond the prescribed limits. It would be appropriate for regulations to be modified taking into account these particular features, ie high ash value for Castanea, high acidity for Thymus, Metcalfa honeydew, Arbutus and Erica, low diastase values for Robinia, Taraxacum, Arbutus and Erica, high sucrose content for Hedysarum, and low reducing sugars for honeydew honeys.

\section{CONCLUSIONS}

The data summarized in the tables give a fairly good description of 14 Italian unifloral honeys. Some of them are more easily identifiable due to the presence of particular characteristics, whereas others have an 'average' behaviour.

In summary, it is not possible to evaluate exactly how much nectar of one or other botanical species there is in a honey and, in the last analysis, this may not even be so important. Indeed, what is really of interest is that a unifloral honey complies with what it is expected to be, ie that an orange honey looks, smell and tastes like an orange honey. So, if, for example, it contains a certain quantity of Hedysarum nectar that does not substantially alter its organoleptic and analytical picture, this is less important than a low contamination from a 'stronger' nectar capable of modifying its characteristics.

In general, we believe that only a global examination, which takes into account all the analytical aspects, can lead to a reasonably correct judgment, because no simple parameter can assure an exact diagnosis.

Even melissopalynological analysis gives rise to important interpretation problems; often the sole presence of a dominant pollen 
$(>45 \%$ ) was considered the key to 'uniflorality', whereas it is now currently accepted that microscopic analysis alone is not sufficient to establish the botanical origin of honeys and that, in any case, each honey type has its own palynological pattern which must be known before drawing any conclusions.

As far as the physicochemical characteristics are concerned, a statistical study carried out by cluster analysis (Stefanini, 1984, 1988; Persano Oddo et al, 1988b) showed that this analytical approach has a significant discriminating power. However, a more or less widespread overlapping of the highest values of one group with the lowest values of the next group occurs in almost all the parameters examined. On the other hand, the variability of the product makes it difficult to establish precise limits.

An organoleptic analysis carried out by an expert can provide a fairly precise evaluation. It should not to be forgotten that the final judge, the consumer, can only appreciate the organoleptic properties. However, strictly it depends on the taster's ability, and it is difficult to express the results in an objective and repeatable way that can be used by others.

To conclude, we think that a reliable diagnosis will only be achieved by means of an organoleptic examination integrated by microscopic and, physicochemical data and, above all, correctly interpreted by an analyst who has a good knowledge of the product.

\section{Résumé - Caractérisation des miels uni-} floraux. Une étude approfondie a été effectuée sur 14 types de miel unifloral sur la base des propriétés organoleptiques, microscopiques (analyse mélissopalynologique qualitative et quantitative) et physico-chimiques (couleur, humidité, cendres, HMF, diastase, $\mathrm{pH}$, acidité totale, conductibilité électrique, rotation spécifique et sucres). Les miels analysés proviennent des origines botaniques suivantes : Arbutus unedo L,
Castanea sativa Mill, Citrus spp, Erica arborea L, Eucalyptus camaldulensis Dehnh, Hedysarum coronarium L, Helianthus annuus L, Rhododendron spp, Robinia pseudoacacia L, Taraxacum officinale Web, Thymus capitatus Hofmgg et LK, Tilia spp, miel de miellat de sapin et miel de miellat produit par Metcalfa pruinosa. La description des caractéristiques organoleptiques (tableau I) fournit des renseignements essentiellement orientatifs, à cause de la difficulté à traduire en paroles les perceptions sensorielles. Ce type d'analyse est étroitement lié à l'expérience du dégustateur. Les analyses mélissopalynologiques (tableau I) montrent que les miels de Robinia, Citrus, Tilia, Rhododendron, Arbutus and Thymus sont sous-représentés ; ceux de Castanea et Eucalyptus sur-représentés ; Erica et Hedysarum appartiennent à la classe normale; Taraxacum, Helianthus et les miels de miellat ont un comportement variable. Les propriétés physico-chimiques (tableaux II, III) des différents miels unifloraux sont les suivantes : Robinia : couleur claire, valeurs basses de conductibilité électrique, cendres, diastase, glucose et rapport glucose/eau (G/W) ; valeurs élevées de fructose et du rapport fructose/glucose (F/G). Hedysarum : couleur claire, valeurs basses de conductibilité électrique, cendres, $\mathrm{pH}$; valeurs élevées d'acidité. Rhododendron : couleur claire, valeurs basses de conductibilité électrique, cendres et rotation spécifique. Citrus : couleur claire, valeurs basses de conductibilité électrique, cendres et diastase. Castanea : couleur foncée, valeurs élevées de $\mathrm{pH}$, cendres, conductibilité, fructose et rapport F/G. Miel de miellat de sapin : couleur foncée, valeurs élevées de $\mathrm{pH}$, cendres, conductibilité, di- et trisaccharides (mélézitose) ; valeurs basses de monosaccharides, valeurs positives de rotation spécifique. Miel de miellat produit par Metcalfa pruinosa : couleur foncée, valeurs élevées de $\mathrm{pH}$, cendres, conductibilité, acidité, diastase, di- et trisaccharides (maltotriose), valeurs basses de monosac- 
charides, valeurs positives de rotation spécifique. Helianthus : couleur jaune vive, valeurs élevées de monosaccharides (glucose) et du rapport $G / W$, valeurs basses du rapport $F / G$. Taraxacum: valeurs élevées de monosaccharides (glucose) et du rapport G/W, valeurs basses de diastase, acidité et du rapport F/G. Erica : couleur foncée avec des nuances orange, valeurs élevées d'acidité, eau, HMF, cendres et conductibilité, valeurs basses de diastase. Arbutus: valeurs élevées d'acidité, eau, cendres et conductibilité, valeurs basses de diastase. Thymus : valeurs élevées d'acidité et diastase, valeurs fortement négatives de rotation spécifique. Eucalyptus et Tilia ont un comportement moyen par rapport à tous les paramètres examinés et sont donc moins facilement identifiables. Par conséquent l'examen organoleptique est particulièrement important pour ces miels. D'une façon générale, nous pouvons conclure qu'un diagnostic fiable des miels unifloraux requiert une analyse organoleptique intégrée par les données mélissopalynologiques et physico-chimiques et, surtout, interprétée correctement par un analyste ayant une bonne connaissance du produit.

miel / Italie / mélissopalynologie / caractérisation physico-chimique / analyse organoleptique

\section{Zusammenfasung - Charakterisierung} von Sortenhonigen. An 14 Arten italienischer Sortenhonige wurde eine ausführliche Studie zu ihrer Charakterisierung durchgeführt. Diese umfasste organoleptische, mikroskopische (qualitative und quantitative melissopalynologische Analysen) und physikalisch-chemische Eigenschaften (Färbung, Wassergehalt, Asche, HMF, Diastase, $\mathrm{pH}$, Säuregehalt, Leitfähigkeit, optische Drehung und Zucker). Die botanische Herkunft der untersuchten Honige war: Arbutus unedo L, Castanea sativa Mill, Citrus spp, Erica arborea L, Eucalyptus caldulensis
Denh, Hedisarum coronarium L, Helianthus annuus L, Rhododendron spp, Robinia pseudacacia L, Taraxacum officinale Web, Thymus capitatus Hofmgg et LK, Tilia spp, Honigtauhonig von Abies und Metcalfa pruinosa. Die Beschreibung der organoleptischen Merkmale (Tabelle I) dient nur zur generellen Information, da Sinneseindrücke schwer in Worte gefaßt werden können. Diese Analysen sind sehr stark von Fähigkeiten und Erfahrung der Schmecker abhängig. Die melissopalynologische Analyse (Tabelle I) zeigt, daß die Honige von Robinia, Citrus, Tilia, Rhododendron, Arbutus und Thymus unterrepräsentiert sind; Honige von Castanea und Eucalyptus sind überrepräsentiert; Erica und Hedysarum liegen im mittleren Bereich während Taraxacum, Helianthus und die Honigtauhonige sehr variabel sind. In den physikalisch-chemischen Eigenschaften (Tabellen II, III) wurden die verschiedenen Sortenhonige wie folgt charakterisiert: Robinia: helle Färbung, niedrige Werte bei Leitfähigkeit, Asche, Diastase, Glucose sowie ein niedriges Verhältnis von Glukose/Wasser; hoher Fructosegehalt und hohes Verhältnis von Fructose/Glucose. Hedysarum: helle Farbe, niedrige Werte bei Leitfähigkeit, Asche, $\mathrm{pH}$; hoher Säuregehalt. Rhododendron: helle Farbe, niedrige Werte bei Leitfähigkeit, Asche und der optischen Drehung. Citrus: helle Farbe, niedrige Werte bei Leitfähigkeit, Asche und Diastase. Castanea: dunkle Farbe, hohe Werte bei $\mathrm{pH}$, Asche, Leitfähigkeit, Fructose und dem Verhältnis von Fructose/Glucose. Abies Honigtau: dunkle Farbe, hohe Werte bei $\mathrm{pH}$, Asche, Leitfähigkeit, Di- und Trisacchariden (Melezitose); niedriger Gehalt an Monosacchariden und positive optische Drehungswerte. Honigtau von Metcalfa pruinosa: dunkle Farbe, hohe Werte bei $\mathrm{pH}$, Asche, Leitfähigkeit, Säuregehalt, Diastase, Di- und Trisacchariden (Maltotriose); niedriger Gehalt an Monosacchariden und positive optische Drehungswerte. Helianthus: hellgelbe Farbe, hoher Gehalt an Monosac- 
chariden (Glucose) und hohes Verhältnis von Glucose/Wasser; niedriges Verhältnis von Fructose/Glucose. Erica: dunkle Farbe mit oranger Tönung; hohe Werte bei Säuregehalt, Wassergehalt, HMF, Asche und Leitfähigkeit; niedriger Diastasewert. Arbutus: hohe Werte bei Säuregehalt, Wassergehalt, Asche und Leitfähgigkeit; niedrige Diastasewerte. Thymus: hoher Säure- und Diastasegehalt, stark negative optische Drehungswerte. Eucalyptus und Tilia nehmen in allen untersuchten Parametern eine Mittelstellung ein und können daher weniger leicht identifiziert werden. Bei diesen Honigen ist die organoleptische Analyse besonders wichtig. Letztendlich kann eine verläßliche Sortendiagnose nur durch die Integration von organoleptischer Überprüfung mit mikroskopischen und physikalisch-chemischen Werten erreicht werden, für deren korrekte Interpretation ein Untersucher mit guten Kenntnissen des Produkts erforderlich ist.

\section{Honig / Italien / Melissopalynologie / phy- sikalisch-chemische Charakterisierung / organoleptische Analyse}

\section{REFERENCES}

Accorti M, Persano Oddo L, Piazza M, Sabatini A (1986) Schede di caratterizzazione delle principali qualit_di miele italiano. Apicoltura 2, supplement

Accorti M, Piazza M, Persano Oddo L (1983) Electrical conductivity and ash in honeys. XXIX Inter Congr of Apiculture, Apimondia, Budapest, 343

Accorti M, Piazza M, Persano Oddo L (1987) La conductivité électrique et le contenu en cendre du miel. Apiacta XXII, 19-20

Aubert S, Gonnet M (1983) Mesure de la couleur des miels. Apidologie 14, 105-118

Barbattini R, Greatti M, lob M, Sabatini A, Marcazzan Gl, Colombo R (1991) Osservazioni su Metcalfa pruinosa (Say) e indagine sulle caratteristiche del miele derivato dalla sua melata. Apicoltura 7,113135

Battaglini M, Bosi G (1973) Caratterizzazione chimicofisica dei mieli monoflora sulla base dello spettro glucidico e del potere rotatorio specifico. Scienza e Tecnologia degli Alimenti III 4, 217-221
Codex Alimentarius Commission (1989) Codex standard for sugars (honey). Worldwide standard. FAOWHO, CAC Vol 3, ed 1, suppl 2, Rome

European Economic Community (1974) EEC Council directive of 22 July 1974 on the harmonisation of the laws of the members states relating to honey. Off J Eur Comm No L221, 10-14

Gonnet M, Vache G (1985) Le goût du miel. UNAF, Paris

Louveaux J, Maurizio A, Vorwohl G (1978) Methods of melissopalynology. Bee world 59, 139-157

Louveaux J, Pourtallier MP, Vorwohl G (1973) Méthodes d'analyses des miels. Conductivité. Bul Tech Apic XVI, 2

Junk WR, Pancoast HM (1973) Handbook of Sugars. Avi Publ Co, USA, 295

Persano Oddo L, Amorini MT (1985) Analisi melissopalinologica quantitativa dei principali tipi di miele italiano. Apicoltura 1, 105-122

Persano Oddo L, Baldi E, Piazza MG (1986) Acidità e $\mathrm{pH}$ nei principali mieli uniflorali italiani. Apicoltura 2, 145-154

Persano Oddo L, Piazza MG, Accorti M (1988a) Diagnosis of unifloral boneys. I. Present knowledge and problems. Apicoltura 4, 1-12

Persano Oddo L, Stefanini R, Piazza MG, Accorti M (1988b) Diagnosis of unifloral honeys. III. Application of a statistical approach to honey classification. Apicoltura 4, 27-38

Persano Oddo L, Baldi E, Accorti M (1990) Diastatic activity in some unifloral honeys. Apidologie 21, 17-24

Persano Oddo L, Piazza MG, Sabatini AG (1991) Schede di caratterizzazione del miele di tiglio e del miele di melata di Metcalfa pruinosa. Apicoltura 7, 151-159

Piazza MG, Accorti M, Persano Oddo L (1991) Electrical conductivity, ash, colour and specific rotatory power in Italian unifloral honeys. Apicoltura 7, 51-63

Sabatini AG, Nanetti A, Maurizi M, Lercker G (1984) Studio sull'origine botanica dei mieli attraverso il profilo gascromatografico dei componenti neutri. Riv merceol 23, 71-81

Sabatini AG, Persano Oddo L, Piazza MG, Accorti M, Nanetti $A$ (1989) Glucide spectrum in the main Italian unifloral honeys. I. Fructose and glucose. Apicoltura 5, 35-46

Sabatini AG, Persano Oddo L, Piazza MG, Accorti M, Marcazzan G (1990) Glucide spectrum in the main Italian unifloral honeys. II. Di- and trisaccharides. Apicoltura 6, 63-70

Stefanini R (1984) Variability and cluster analysis of Italian honeys. Apiacta XIX, 109-114

Stefanini R (1988) Diagnosis of unifloral honeys. II. Numerical taxonomy of honey and statistical diagnostic test of its botanical origin. Apicoltura 4, 13-26

White JW Jr, Riethof FL, Subers MH, Kushnir I (1962) Composition of American Honeys. Tech Bull USDA, 1261, Washington, DC, USA 